\title{
Stress Management During Covid-19 Pandemic
}

\author{
Girija $\mathbf{C}^{\mathbf{1}}$, Dr. S. Syamaladevi ${ }^{2}$ \\ ${ }^{1}$ Assistant Professor - Commerce \& Management Studies, M.P.M.M.S.N Trusts College, Shoranur, Palakkad, Kerala \\ ${ }^{2}$ Associate Professor - Department of Commerce, M.V. Muthaiah Govt. Arts College for Women, Dindigul, Tamilnadu
}

\begin{abstract}
The outbreak of COVID-19 may be stressful for people. Fear and anxiety about a disease can be overwhelming and cause strong emotions in adults and children. Stress during COVID-19 can be taken as emotional; if people are living with an anxiety disorder. There are so many things outside of our control, how long the pandemic lasts, how other people behave, and what's going to happen in our communities. The main objective of this study is to analyze the level of stress among students and the stress management techniques adopted by people to reduce stress during this pandemic situation. The study includes both primary and secondary data.
\end{abstract}

Keywords: Stress management, COVID-19, WHO, CDC.

\section{INTRODUCTION}

Stress is the normal reaction of the body has when changes occur. It can respond to these changes physically, mentally, or emotionally. Stress is a normal part of life. The human body is designed to experience stress and react to it. Stress can be positive, keeping as alert motivated and ready to avoid danger. Stress becomes negative when the person faces continuous challenges without relief or relaxation between stressors.

Stress management consists of making changes to live if we are in a constant stressful, situation preventing stress by practicing self-care and relaxation and managing your response to stressful situations when they do occur. Studies have shown that a healthy amount of manageable stress can lead to increased brain functioning, a boosted immune system, and better preparation for future stressful situations, which can positively affect emotional health with your work and home life.

During this COVID-19 pandemic situation, people feel stress, fear, and anxiety. Social distancing affects every part of our lives including relationships, finances, transportation, jobs, education, and healthcare. Routines are essential because they create a sense of normalcy and control in our lives. Lack of social support leads to increase stress among people. When everyone is experiencing the same sense of uncertainty, there is no real 'anchor' to help and manage stress.

Stress management is essential for good physical health and it is especially important right now as the world addresses the COVID-19 Pandemic. When people are more pessimistic, depressed, or anxious their immune system goes down and produces more stress hormones, reducing our immunity and increasing inflammation. Stress can also put a strain on our health, relationships, and productivity.

Stress during an infectious disease outbreak can sometimes cause the following:

- $\quad$ Fear and worry about your health and the health of loved ones.

- Financial situation or job.

- Loss of support of services.

- $\quad$ Changes in sleep or eating pattern.

- Difficulty in sleeping or concentrating.

- Worsening of chronic health problems.

- Worsening of mental health condition.

- $\quad$ Increased use of tobacco or alcohol and other substances.

- Increase in domestic violence against women.

- $\quad$ Sadness, tearfulness, loss of interest in usable enjoyable activities.

- Restlessness or agitation

- Feeling helpless

- $\quad$ Feeling disconnected from others.

\section{Statement of Problem}

Novel Corona Virus Disease (COVID-19) has rapidly crossed borders, infecting people throughout the whole world. This situation has led to a massive public reaction; the media has been reporting across borders to keep all informed about the pandemic situation. All these things are creating a lot of concern for people leading to an increase in the level of stress 


\section{International Advanced Research Journal in Science, Engineering and Technology}

Vol. 8, Issue 6, June 2021

\section{DOI: $10.17148 / I A R J S E T .2021 .8646$}

and anxiety. This study focused to analyze the level of stress and the stress management techniques adopted by people to reduce the stress during this COVID-19 pandemic situation.

\section{REVIEW LITERATURE}

Everly Jr, G. S., Flannery Jr, R. B., \& Mitchell, J. T. (2000). Critical Incident Stress Management (CISM) comprises a range of crisis intervention services that usually include pre-crisis training, individual crisis counseling, group debriefing, and post-incident referral for primary and secondary victims. CISM is utilized to address the aftermath of violent acts and has evolved from earlier crisis intervention and group psychological debriefing procedures. These approaches have been used throughout the world, and CISM is emerging as a standard of care. This article reviews the literature on crisis intervention, group debriefing, and CISM interventions within a methodological context. The strengths and weaknesses of the literature as a whole are presented. Implications of the findings are discussed.

Fatima, S., Bukhari, S., \& Pacella, J. (2020). The coronavirus disease of 2019 (COVID-19) is a global medical crisis that has posed immense challenges to medical fraternity worldwide. COVID-19 is caused by Severe Acute Respiratory Syndrome - Corona Virus - 2 (SARS-CoV-2) that targets the host's Angiotensin-Converting Enzyme -2 (ACE2) receptors present in the lungs, heart, blood vessels, kidneys, and intestines. Symptoms are primarily respiratory in origin but the disease has the propensity to involve all organ systems quickly to cause multi-organ failure and death. The patients with pre-existing cardiovascular diseases are more prone to contracting infection, and the involvement of the cardiovascular system itself has been linked to increased morbidity and mortality in COVID-19 patients. Therefore, learning about the cardiovascular implications of SARS-CoV-2 infection is of paramount importance for the cardiology world at this juncture. Herein, we review the initial literature relevant to SARS-CoV-2 associated cardiovascular pathology, highlighting cardiac manifestations, biomarker utility, and therapeutic landscape in the present era of COVID-19.

Luo, M., Guo, L., Yu, M., \& Wang, H. (2020). The coronavirus disease 2019 (COVID-19) pandemic has caused enormous psychological impact worldwide. We conducted a systematic review and meta-analysis on the psychological and mental impact of COVID-19 among healthcare workers, the general population, and patients with higher COVID19 risk published between 1 Nov 2019 to 25 May 2020. We conducted literature research using Embase, PubMed, Google scholar, and WHO COVID-19 databases. Among the initial search of 9207 studies, 62 studies with 162,639 participants from 17 countries were included in the review. The pooled prevalence of anxiety and depression was 33\% (95\% confidence interval: $28 \%-38 \%$ ) and $28 \%$ (23\%-32\%), respectively. The prevalence of anxiety and depression was the highest among patients with pre-existing conditions and COVID-19 infection (56\% [39\%-73\%] and 55\% [48\%-62\%]), and it was similar between healthcare workers and the general public. Studies from China, Italy, Turkey, Spain, and Iran reported higher-than-pooled prevalence among healthcare workers and the general public. Common risk factors included being women, being nurses, having lower socioeconomic status, having high risks of contracting COVID-19, and social isolation. Protective factors included having sufficient medical resources, up-to-date and accurate information, and taking precautionary measures. In conclusion, psychological interventions targeting high-risk populations with heavy psychological distress are in urgent need.

Luzzi, V., Ierardo, G., Bossù, M., \& Polimeni, A. (2020). During the period of health emergency linked to the current COVID-19 pandemic, the management of children's oral health presents specific problems related to the infectious spread of the disease. These problems must be faced on the one hand by acting on the oral health prevention methods, and the other by implementing specific protocols relating both to the conditions of oral pathologies that normally do not represent an emergency and to those clinical situations that fall into the category of pediatric dental emergencies. In this perspective, in addition to defining rigorous and highly effective infection control protocols in dental settings, it is of fundamental importance to work on remote communication and education aimed at maintaining the oral health of the children. This article, after an analysis of the risk factors from COVID-19 associated with pediatric dental treatment, presents a series of considerations on potential oral prevention strategies and on the management of emergency and non-emergency dental procedures in a context of disease transmission control, proposing new approaches and models of treatment based also on remote interaction techniques which will then retain their usefulness even at the end of the current emergency period. Liu, X., Liu, J., \& Zhong, X. (2020). This study conducted in mainland China was aimed to explore the cognition, psychological state, anxiety and depression level of college students during coronavirus disease 2019(COVID-19) epidemic, to understand the psychological dynamics of college students under stress. The data of 509 college students were collected by an Internet questionnaire. And the Self-Rating Anxiety Scale and Center for Epidemiological Studies Depression Scale were used to assess anxiety and depression symptoms, respectively. During the COVID-19 epidemic, the majority of college students strongly agreed to reduce outgoing and gathering, accounting for $77.21 \%$. There were statistical differences between different genders of college students in the unease and panic emotion of risk exposure. Moreover, the anxiety and depression levels of college students in China during the COVID-19 epidemic were higher than the national norm level. 


\section{OBJECTIVES OF STUDY}

1. To analyze the level of stress among people during COVID-19 Pandemic.

2. To study the stress management techniques adopted by people to reduce stress during COVID-19 Pandemic.

\section{RESEARCH METHODOLOGY}

The research methodology includes the various steps involved in the particular research and systematically solving the problem with the objective of the fact.

\subsection{Sources of Data}

Both primary and secondary sources of data were used to carry out the study.

Primary data were collected through questionnaires among people.

Secondary data were collected from journals, research articles, and websites.

\subsection{Sampling technique}

The sampling technique used for the study is convenience sampling.

\subsection{Sample size}

The study was conducted by taking a sample of 133 respondents.

\subsection{Area of study}

The data was collected through google form from various respondents residing in India

\section{DATA ANALYSIS AND INTERPRETATION}

\subsection{Table - 1 Gender}

\begin{tabular}{|l|r|r|}
\hline \multicolumn{1}{|c|}{ Gender } & Frequency & Percent \\
\hline Female & 89 & 66.9 \\
\hline Male & 44 & 33.1 \\
\hline Total & 133 & 100.0 \\
\hline
\end{tabular}

(Source: Primary Data)

Interpretation: From table 1 shows that $66.9 \%$ of respondents are female and $33.1 \%$ are male.

\subsection{Table - 2 Age Group}

\begin{tabular}{|l|c|c|}
\hline Age Group & Frequency & Percent \\
\hline $20-25$ & 74 & 55.6 \\
\hline $26-30$ & 3 & 2.3 \\
\hline $31-35$ & 2 & 1.5 \\
\hline Under 20 & 54 & 40.6 \\
\hline Total & 133 & 100.0 \\
\hline
\end{tabular}

(Source: Primary Data)

Interpretation: Table 2 indicates the age group. Out of 133 respondents, $55.6 \%$ are in the age group $20-25,40.6 \%$ are in the age group of under $20,2.3 \%$ belong t0 $26-30$ and only $1.5 \%$ are in the age group of $31-35$.

\subsection{Table - 3 Educational Qualification}

\section{(Source: Primary Data)}

\begin{tabular}{|l|c|c|}
\hline \multicolumn{1}{|c|}{ Educational Qualification } & Frequency & Percent \\
\hline Degree / Diploma & 71 & 53.4 \\
\hline Higher Secondary & 24 & 18.0 \\
\hline Master Degree & 31 & 23.3 \\
\hline Others & 5 & 3.8 \\
\hline PhD & 1 & .8 \\
\hline Secondary & 1 & .8 \\
\hline Total & 133 & 100.0 \\
\hline
\end{tabular}

Interpretation: Table 3 shows the perception of the respondents based on their qualifications. It is classified into 6 categories $.53 .4 \%$ of respondents are graduate, $23.3 \%$ of respondents are postgraduates, $18 \%$ of respondents are belonging to higher secondary. 
International Advanced Research Journal in Science, Engineering and Technology

Vol. 8, Issue 6, June 2021

DOI: $10.17148 /$ IARJSET.2021.8646

5.4 Table - 4 Upset because of unexpected happening

\begin{tabular}{|l|c|c|}
\hline Option & Frequency & Percentage \\
\hline Rarely & 12 & 9.0 \\
\hline Never & 17 & 12.8 \\
\hline Often & 13 & 9.8 \\
\hline Sometimes & 84 & 63.2 \\
\hline Very often & 7 & 5.3 \\
\hline Total & 133 & 100.0 \\
\hline
\end{tabular}

(Source: Primary Data)

Interpretation: Table 4 shows the upset of respondents due to unexpected happening.63.2\% respondents opined that they feel upset sometimes by happening pandemic situations.

5.5 Table -5 Ability to control the important things in life

\begin{tabular}{|l|c|c|}
\hline Option & Frequency & Percent \\
\hline Rarely & 32 & 24.1 \\
\hline Never & 30 & 22.6 \\
\hline Often & 12 & 9.0 \\
\hline Sometimes & 50 & 37.6 \\
\hline Very often & 9 & 6.8 \\
\hline Total & 133 & 100.0 \\
\hline
\end{tabular}

(Source: Primary Data)

Interpretation: Table 5 shows the ability to control the important things in life. Out of 133 respondents, $37.6 \%$ are opined that in certain situations they are not able to control things life. $22.6 \%$ are not facing such a problem

5.6 Table - 6 Ability to handle problems

\begin{tabular}{|l|c|c|}
\hline Option & Frequency & Percent \\
\hline Rarely & 22 & 16.5 \\
\hline Never & 8 & 6.0 \\
\hline Often & 27 & 20.3 \\
\hline Sometimes & 53 & 39.8 \\
\hline Very often & 23 & 17.3 \\
\hline Total & 133 & 100.0 \\
\hline
\end{tabular}

(Source: Primary Data)

Interpretation: Table 6 indicates the ability to handle problems. 39.8\% of respondents reveal that they have the ability in sometimes only. $20.3 \%$ are facing problems.

5.7 Table - 7 cope with things

\begin{tabular}{|l|c|c|}
\hline Option & Frequency & Percent \\
\hline Rarely & 28 & 21.1 \\
\hline Never & 31 & 23.3 \\
\hline Often & 9 & 6.8 \\
\hline Sometimes & 64 & 48.1 \\
\hline Very often & 1 & .8 \\
\hline Total & 133 & 100.0 \\
\hline
\end{tabular}

\section{(Source: Primary Data)}

Interpretation: Table 7 indicates the ability to cope with things. $48.1 \%$ of respondents opined that they are sometimes coping with things and changes.23.3\% does not have such problems.

\subsection{Table - 8 Control irritation}

\begin{tabular}{|l|c|c|}
\hline \multicolumn{1}{|c|}{ Option } & Frequency & Percent \\
\hline Rarely & 25 & 18.8 \\
\hline Never & 27 & 20.3 \\
\hline Often & 16 & 12.0 \\
\hline
\end{tabular}


DOI: $10.17148 /$ IARJSET.2021.8646

\begin{tabular}{|l|c|c|}
\hline Sometimes & 61 & 45.9 \\
\hline Very often & 4 & 3.0 \\
\hline Total & 133 & 100.0 \\
\hline
\end{tabular}

(Source: Primary Data)

Interpretation:8 Table 8 shows the control during irritation. $45.9 \%$ are sometimes irritated. $20.3 \%$ are getting control during that time.

5.9 Table - 9 Angry because of things that were outside the control

\begin{tabular}{|l|c|c|}
\hline Option & Frequency & Percent \\
\hline Rarely & 27 & 20.3 \\
\hline Never & 26 & 19.5 \\
\hline Often & 16 & 12.0 \\
\hline Sometimes & 59 & 44.4 \\
\hline Very often & 5 & 3.8 \\
\hline Total & 133 & 100.0 \\
\hline
\end{tabular}

(Source: Primary Data)

Interpretation: Table 9 shows the level of confidence. $44.4 \%$ thought that things are sometimes out of control. $19.5 \%$ never felt so.

\subsection{Table - 10 Types of stress Arguments at home}

\begin{tabular}{|l|r|r|}
\hline Option & Frequency & \multicolumn{2}{|c|}{ Percent } \\
\hline Always & 4 & 3.0 \\
\hline Frequently & 6 & 4.5 \\
\hline Not at All & 46 & 34.6 \\
\hline Rarely & 39 & 29.3 \\
\hline Some times & 38 & 28.6 \\
\hline Total & 133 & 100.0 \\
\hline
\end{tabular}

(Source: Primary Data)

Interpretation:10 showing about types of stress arguments at home. 34.6\% reveals that there are no arguments at home. $29.3 \%$ partially support this.

\subsection{Table - 11 Having to study things do not understand}

\begin{tabular}{|l|r|r|}
\hline Option & Frequency & \multicolumn{2}{|c|}{ Percent } \\
\hline Always & 6 & 4.5 \\
\hline Frequently & 17 & 12.8 \\
\hline Not at All & 23 & 17.3 \\
\hline Rarely & 39 & 29.3 \\
\hline Some times & 48 & 36.1 \\
\hline Total & 133 & 100.0 \\
\hline
\end{tabular}

(Source: Primary Data)

Interpretation: Table 11 shows the stress related to studies. $36.1 \%$ opined that sometimes they felt stress related to studies. $29.3 \%$ are also facing this inability to understand the topics related to their studies.

\subsection{Figure: Stress and health}


DOI: 10.17148/IARJSET.2021.8646

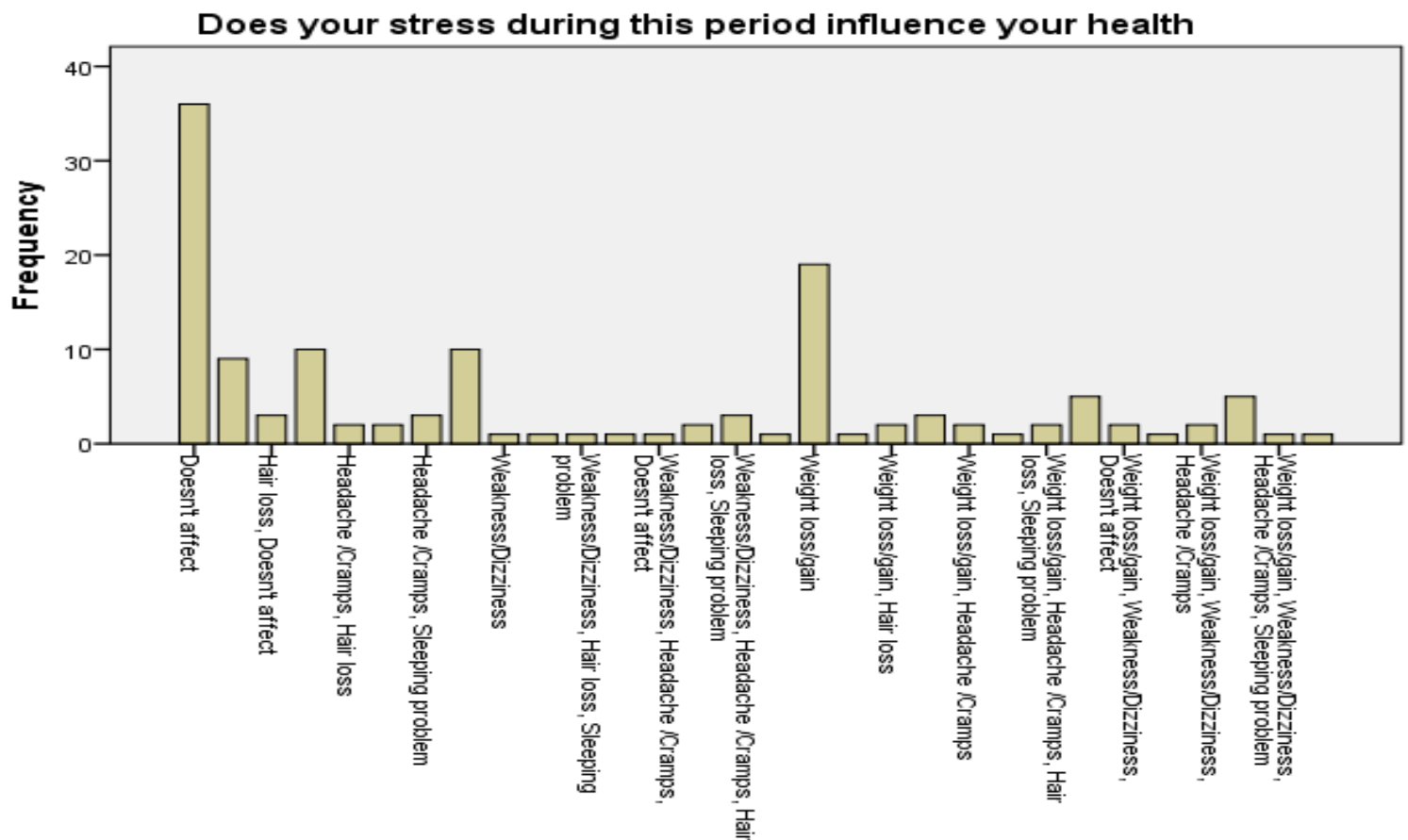

Interpretation: The diagram reveals the effects of stress among the People. Majority of them are suffered from headaches, weight loss, sleeping problems, Dizziness, etc.

\subsection{Copying techniques to manage stress}

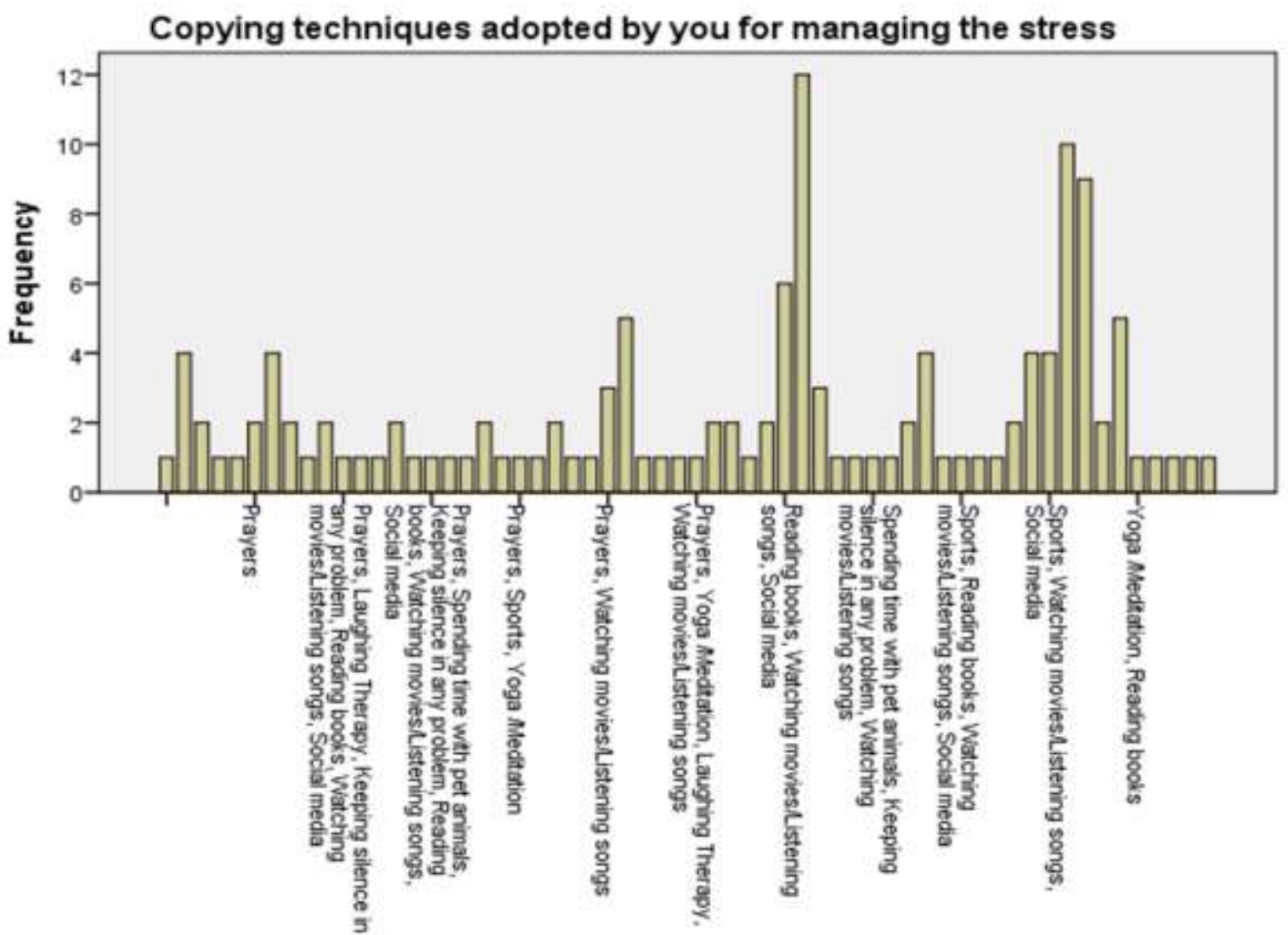




\section{International Advanced Research Journal in Science, Engineering and Technology}

Vol. 8, Issue 6, June 2021

\section{DOI: $10.17148 / I A R J S E T .2021 .8646$}

Interpretation: This diagram indicates the coping mechanism used for reducing stress. For reducing stress coping mechanisms like yoga, meditation, prayers, watching movies, songs, keeping silence, etc. are used by people.

\section{DISCUSSION}

The purpose of this study was to analyze the Stress Management among people during COVID -19 Pandemic. The main objectives of the study were to analyze the level of stress among people during COVID-19 Pandemic and the stress management techniques adopted by people to reduce stress during COVID-19 Pandemic. The data were collected from 133 respondents through online survey. The present investigation has been carried out by taking small sample, from teachers and students. During this COVID -19 Pandemic situation a detailed investigation of stress management among people belonging household work, health care, medical staff, Police force could be carried out.

\section{FINDINGS AND SUGGESTIONS}

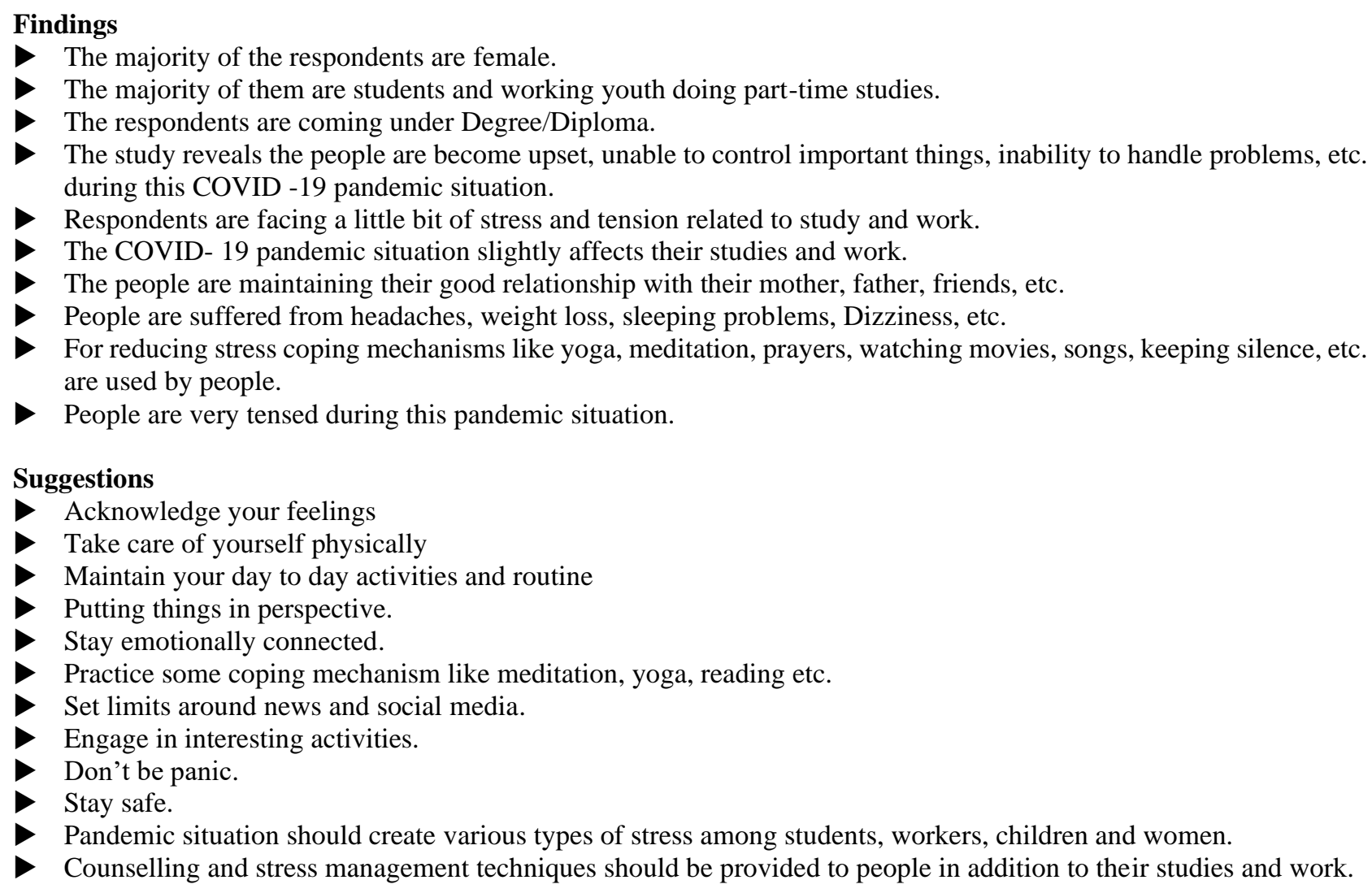

\section{CONCLUSION}

Change is stressful, and stress leads to anxiety, negatively affecting our mental and physical health. While sheltering in place serves the public good, it can affect our mental health. When stressors throw the nervous system out of balance, relaxation techniques such as deep breathing, meditation, and yoga, eat a balanced diet, exercise regularly, get enough sleep can bring you back into a state of equilibrium. Take care of mental and physical health to with stand during this pandemic situation.

\section{REFERENCES}

[1]. Everly Jr, G. S., Flannery Jr, R. B., \& Mitchell, J. T. (2000). Critical incident stress management (CISM): A review of the literature. Aggression and Violent Behavior, 5(1), 23-40.

[2]. Fatima, S., Bukhari, S., \& Pacella, J. (2020). The cardiovascular implications of COVID-19: A Comprehensive Review. Medical Research Archives, 8(5).

[3]. Luo, M., Guo, L., Yu, M., \& Wang, H. (2020). The Psychological and Mental Impact of Coronavirus Disease 2019 (COVID-19) on Medical Staff and General Public-A Systematic Review and Meta-analysis. Psychiatry Research, 113190.

[4]. Luzzi, V., Ierardo, G., Bossù, M., \& Polimeni, A. (2020). COVID-19: Pediatric Oral Health during and after the Pandemics.

[5]. Liu, X., Liu, J., \& Zhong, X. (2020). Psychological State of College Students During COVID-19 Epidemic. Available at SSRN 3552814. 


\section{International Advanced Research Journal in Science, Engineering and Technology}

Vol. 8, Issue 6, June 2021

DOI: 10.17148/IARJSET.2021.8646

[6]. Webliography

[7]. https://www.cdc.gov/coronavirus/2019-ncov/daily-life-coping/managing-stress-anxiety.html

[8]. https://www.piedmont.org/living-better/managing-stress-during-the-covid-19-pandemic

[9]. https://www.osfhealthcare.org/blog/how-to-manage-stress-during-the-covid-19-pan https://www.piedmont.org/living-better/managingstress-during-the-covid-19-pandemicdemic/

[10]. https://www.who.int/docs/default-source/coronaviruse/coping-with-stress.pdf?sfvrsn=9845bc3a_2 